\title{
Evaluation of Biochar Post-Process Treatments to Produce Soil Enhancers and Phosphorus Fertilizers at a Single Plant
}

\author{
Mahmood Laghari ${ }^{1}\left[\right.$ D . Dorette Sophie Müller-Stöver ${ }^{2} \cdot$ Maria Puig-Arnavat $^{1} \cdot$ Tobias Pape Thomsen $^{3}$. \\ Ulrik Birk Henriksen ${ }^{1}$
}

Received: 12 November 2020 / Accepted: 20 January 2021 / Published online: 19 February 2021

(c) The Author(s) 2021

\begin{abstract}
This study evaluates the potential to produce phosphorus (P)-rich fertilizer substrates with high plant availability as well as carbon (C)-rich biochar with soil enhancement properties in a single slow-pyrolysis plant. Campaign-based production or co-production of soil enhancers and fertilizer substrates may increase the potential societal value of slow pyrolysis plants. The assessment focus on conventional slow pyrolysis operated at $600^{\circ} \mathrm{C}$ to produce biochar from various substrates as well as two options for post-process char treatments-char oxidation at $550{ }^{\circ} \mathrm{C}$ and char steam gasification at $800{ }^{\circ} \mathrm{C}$, as a potential way to improve substrate fertilizer value. Four P-rich biomass residues including municipal sewage sludge (SS), biogas fiber (BF), cattle manure (CM), and poultry manure (PM) as well as two C-rich biomasses: wood chips (WC) and wheat straw (WS), were tested. Production yields of biochar and ash from char oxidation and steam gasification were compared and the materials were characterized to be used as soil enhancers and P-fertilizers through direct analysis and soil incubation studies with two different agricultural soils. All thermal treatments increased the concentration of the plant nutrients P, potassium and magnesium in the resulting biochar and ashes compared to the dry biomass. At the same time, concentrations of nitrogen and sulfur were reduced. The dry biomasses generally increased the amount of available $\mathrm{P}$ in the soils to a greater extent than biochar or ashes at an application rate of $80 \mathrm{mg} \mathrm{P} / \mathrm{kg}$ soil. The P-rich biochar and ash made from BF, CM and PM had higher $P$ fertilizer values than those made from SS. In terms of thermal processes, pyrolysis with subsequent char steam gasification was found to be the best option for high P availability in both soils, except for operation on SS where the oxidized char gave the best results. The $\mathrm{C}$-rich biochars made from wood and wheat straw both showed potential for improving soil properties including soil organic matter (SOM) content, cation exchange capacity (CEC) and water holding capacity (WHC). The study shows that campaign operation of slow pyrolysis with the option for char steam gasification is a viable option for producing fertilizer substrates with high levels of plant available $\mathrm{P}$ as well as biochar with substantial soil enhancing properties on a single plant. In addition, results also indicate that direct co-pyrolysis of P-rich substrates-especially BF and CM, with any of the two tested C-rich substrates-without subsequent char treatment may be a sufficiently well integrated option for combined soil fertility and soil $\mathrm{P}$ fertilization management.
\end{abstract}

Mahmood Laghari

mahl@kt.dtu.dk; mlaghari7@gmail.com

1 Department of Chemical and Biochemical Engineering, Technical University of Denmark, Lyngby, Denmark

2 Department of Plant and Environmental Sciences, University of Copenhagen, Copenhagen, Denmark

3 Department of People and Technology, Roskilde University, Roskilde, Denmark 


\section{Graphic Abstract}

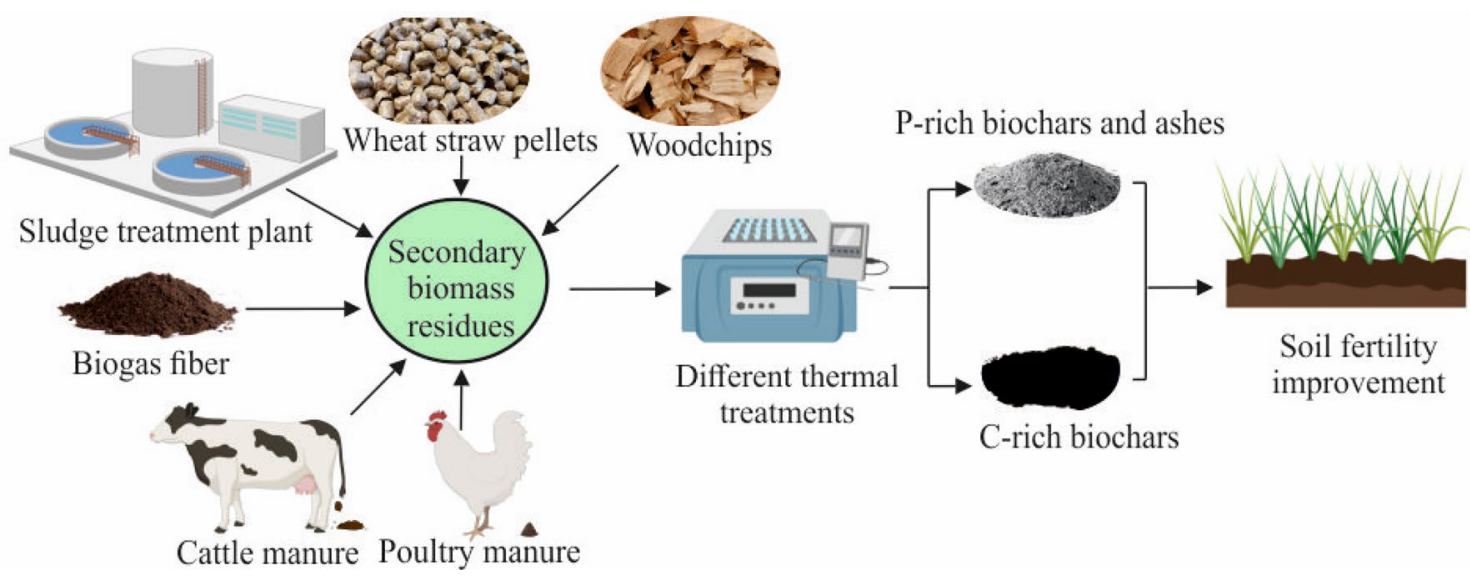

Keywords Organic waste $\cdot$ Biomass residues $\cdot$ Available phosphorus $\cdot$ Pyrolysis $\cdot$ Char oxidation $\cdot$ Char gasification

\section{Statement of Novelty}

This study investigated a novel approach to produce high quality phosphorus (P)-rich fertilizer substrates with high plant availability as well as carbon (C)-rich biochar with soil enhancement properties in a single slow-pyrolysis plant. The novelty is based on (i) assessment of dual purpose char/ash production in a single pyrolysis plant under similar operation conditions and (ii) assessment of P fertilizer quality optimization potentials applying two different thermal post-process char treatment processes. Campaignbased production or co-production of soil enhancers and fertilizer substrates may increase the potential societal value of slow pyrolysis plants.

\section{Introduction}

Phosphorus (P) is an important macronutrient for plants. Phosphate rock, which is the primary source for mineral $\mathrm{P}$ fertilizer and a non-renewable resource, is rapidly depleting due to the increasing demand of mineral $\mathrm{P}$ fertilizers globally [1]. The major (>90\%) global reserves of P rock belong to a few countries including Morocco, China, Russia, Australia and the United States. Due to this uneven geographic distribution of the $\mathrm{P}$ rock combined with the limited global reserves, increasing demand and sub-optimal use-reuse management strategies, there is a great concern about $\mathrm{P}$ scarcity in the near future [2,3]. It is therefore essential to develop better methods for managing $\mathrm{P}$ use and re-use to secure the future productivity of the world's agricultural production systems.
A significant fraction of $\mathrm{P}$ used in agriculture ends up in municipal wastewater sludge, manure, biogas fibers (BF) and other secondary organic resources [3, 4]. Therefore, the recycling of $\mathrm{P}$ from such P-rich waste resources or byproducts is often suggested as a way to reduce the pressure on the mined fossil-P resource, and to contribute to the development of a more circular economy [5, 6]. Furthermore, it is essential to develop strategies to redistribute $\mathrm{P}$ from urban regions [7] or agricultural regions with a high soil $\mathrm{P}$ status (typically with a specialization in livestock production where large amounts of manure are applied) to regions with $P$ deficient soils [5].

Thermochemical platforms, such as gasification and pyrolysis, have been identified as very promising due to their flexibility, thermal efficiency and the ability to simultaneously address biochar valorization and energy utilization [6]. With the proper match between thermal process design and operation, fuel characteristics and end-use, it has previously been proposed to use such thermal processes to close essential P-loops and co-produce non-fossil energy and high quality, stable and easily transportable $\mathrm{P}$ fertilizers from conversion of organic secondary resources $[8,9]$. During pyrolysis and gasification, the organic material is converted into combustible gases, while the majority of inorganic compounds (including $\mathrm{P}$, potassium $(\mathrm{K})$ and micronutrients) are retained in a solid residue (biochar/ash) which is simultaneously cleaned of pathogens, most organic xenobiotics and certain heavy metals $[9,10]$. However, when such technologies are considered for improved P management and development of better use-re-use strategies, one of the key parameters to investigate is the plant availability of $\mathrm{P}$ in the ash/ char products. Previous studies have shown that feedstock, thermal process design, soil characteristics and agricultural 
practice all substantially influence $P$ availability $[11,12]$. Several studies have been published on different ways to extract highly plant available $\mathrm{P}$ from ashes and chars, but often these processes add substantial complexity and cost to the management system [13-17]. More simple modifications of the thermal process, such as the post-process char oxidation recently proposed as an option for enhanced plant availability in char from SS pyrolysis, could therefore be promising alternatives, but this method has not been thoroughly tested on other P-rich substrates [18]. Another relatively simple option for altering char characteristics is postprocess char gasification with steam which is a well-known process for physical char activation [19, 20]. However, postoxidation and steam gasification processes will remove the major part of the carbon $(\mathrm{C})$ from the respective materials, which is responsible for many beneficial effects of biochar on soil fertility parameters, such as water holding capacity (WHC), cation exchange capacity (CEC), $\mathrm{pH}$, bulk density, soil microbial activity etc. [21-26].

Since a high concentration of plant-available $\mathrm{P}$ will typically go hand in hand with a low $\mathrm{C}$ content for materials derived from many of the most relevant secondary organic resources, it may therefore become difficult to solve P-supply and soil fertility issues with the same char. However, producing C-rich chars and P-rich fertilizer materials on the same pyrolysis plant would be another option. Achieving this purpose would increase the flexibility of the pyrolysis plant by converting a variety of feedstock to produce a variety of products with different characteristics and uses, and could potentially increase local societal value of the plant as well. The aim of the current study was therefore to investigate potentials and barriers related to production of P-rich biochars/ashes as well as C-rich biochars from global biomass resources on a single, fixed pyrolysis process with the option for post-process char treatment. The study aimed at; (i) evaluating the potential benefit of post-process char optimization with regard to $\mathrm{P}$ plant availability, (ii) investigating the soil enhancement potentials of C-rich biochars produced at the same temperature, and (iii) discussing potentials and barriers related to co-production and co-application of P-rich substrates and C-rich substrates as an integrated approach to increase $\mathrm{P}$ use efficiency.

\section{Materials and Methods}

\section{Study Design}

The study included laboratory scale production and assessment of P-rich chars and post-process treated chars (ashes) for P-supply, as well as C-rich biochars as potential soil improvers. For the analysis related to the P-supply effects, the $\mathrm{C}$-rich substrates were not included as they contained very small amounts of $\mathrm{P}$ and the required dosing would be unreasonable. For the analysis related to the soil properties effects of the C-rich materials, the dosing was conducted on mass basis with high rates of $0.5-5 \%$ based on relevant reported values [27].

\section{Collection of Biomass Residues}

All biomass feedstock samples were collected in Denmark, but represent global type resources. The wastewater sludge, pine woodchips, wheat straw pellets and biogas fibers were collected in January 2019, and the cattle and poultry manure samples were collected in March 2014 and September 2018, respectively. The last two materials have been stored in a freezer at $-18{ }^{\circ} \mathrm{C}$ which has previously been found adequate to retain their original compositions [28], while the other samples were all dry when received. Details about the cattle manure can be found in Thomsen et al. [6]. The poultry manure was collected in Løgumkloster (Denmark) from an organic egg producer. Wheat straw pellets produced from Danish wheat straw without additives were obtained from Højgaard Halmpiller in Thisted (Denmark). Wood chips originated from Danish pine wood grown in Zealand and the biogasfibers were from Maabjerg Energy Center (Denmark). The sewage sludge sample was produced at a representative Danish Mechanical-Biological-Nitrification-Denitrification-Chemical cleaning facility wastewater treatment plant and had been subsequently dried in a commercial steam-drying process (AquaGreen ApS).

\section{Thermal Treatments of Biomass Residues}

\section{Preparation of Biochar: Slow Pyrolysis}

All feedstocks were air dried for several days and then oven dried at $104{ }^{\circ} \mathrm{C}$ for $24 \mathrm{~h}$ just before the pyrolysis. A 50-100 g oven-dried biomass sample was placed in an aluminum tray and housed in an air tight, stainless steel reactor. $\mathrm{N}_{2}$ was purged into the reactor with a flow rate of $6 \mathrm{~L} / \mathrm{min}$ for $20 \mathrm{~min}$ prior to heating to flush out any oxygen from the reactor. Then, the reactor was placed in a preheated furnace and kept at $600{ }^{\circ} \mathrm{C}$ inner reactor temperature for $1 \mathrm{~h}$ with a continuous $\mathrm{N}_{2}$ supply of $1 \mathrm{~L} / \mathrm{min}$. The pyrolysis gas was flared. After $1 \mathrm{~h}$, the furnace was rapidly cooled with an electric fan and the reactor was removed from the furnace when the reactor's internal temperature was below $100{ }^{\circ} \mathrm{C}$. Three replicates were carried out for preparing biochar from each biomass type and mean values were used in calculating the biochar yield. 


\section{Post-Process Oxidation of Biochar}

Char oxidation was conducted as complete annealing of the char in limited air flow [6, 9]. An amount of 50-100 g biochar were spread in aluminum trays and heated in a large furnace at $20^{\circ} \mathrm{C} / \mathrm{min}$ to a maximum temperature of $550{ }^{\circ} \mathrm{C}$. The samples were kept at maximum temperature under an air flow of $2 \mathrm{~L} / \mathrm{min}$ until no further loss in weight was observed. The product from the post-process oxidation of biochar is referred to as oxidation ash in the present study. Three replicates were carried out for post-process oxidation of each type of biochar and the average values were used for calculating the ash yield.

\section{Post-Process Steam Gasification of Biochar}

A Macro Thermogravimetric Analyzer (TGA) was used for the gasification process and also to examine the reactivity of the biochars [6]. 8-10 $\mathrm{g}$ biochar were converted in superheated steam. The TGA reactor was heated to $800{ }^{\circ} \mathrm{C}$ with a heating rate of $10^{\circ} \mathrm{C} / \mathrm{min}$. The sample was heated under a $\mathrm{N}_{2}$ supply of $1 \mathrm{~L} / \mathrm{min}$. Once the reactor temperature reached and stabilized at $800{ }^{\circ} \mathrm{C}$, the $\mathrm{N}_{2}$ supply was replaced with a superheated steam flow of $1 \mathrm{~kg} / \mathrm{h}$. The treatment continued until no further weight loss in the rector was observed. Afterwards, the heating was disconnected and the reactor was rapidly cooled below $100{ }^{\circ} \mathrm{C}$ under $\mathrm{N}_{2}$ supply of $1 \mathrm{~L} /$ min and the gasified char sample was collected from the reactor and stored for further analyses. The product from the post-process steam gasification of biochar is referred to as gasification ash in the present study. Three replicates were carried out for post-process steam gasification of each type of biochar and the average values were used for calculating the ash yield.

\section{Characterization of Biochars and Derived Ashes}

\section{Proximate and Ultimate Analysis of Biomass, Biochar and Ashes}

Moisture content of biomass was determined by placing around $20 \mathrm{~g}$ of air-dried biomass in a drying oven at $105{ }^{\circ} \mathrm{C}$ for $24 \mathrm{~h}$. Moisture content of biochars/ashes was determined following the same procedure but with samples of $1 \mathrm{~g}$ of airdried biochar or ash.

The ash content of the biomass samples was measured by placing $1 \mathrm{~g}$ of oven-dried biomass samples, without further size reduction, in a muffle furnace at $575^{\circ} \mathrm{C}$ for $4 \mathrm{~h}$. The ash content of biochars and ashes was determined according to the test procedures of ASTM D1762-84 [29] by placing $1 \mathrm{~g}$ oven-dried sample in a muffle furnace at $750{ }^{\circ} \mathrm{C}$ for $6 \mathrm{~h}$.
The ultimate analysis of the feedstock, biochars and derived ashes was conducted by combustion. The total content ( $\%$ dry basis) of C, Hydrogen, Nitrogen and Sulphur was determined using an Euro EA-CHNSO Elemental analyzer (HEKAtech $\mathrm{GmbH}$, Germany). Samples of 0.5 to $2.0 \mathrm{mg}$ were packed in tin capsules for testing. Sulfanilamide was used as the standard material for calibration of the analyzer. The oxygen content was calculated by difference. All proximate and ultimate analyses were carried out in triplicate and average values are reported here.

\section{$\mathrm{pH}$ (Water) of Biochar and Ashes}

The $\mathrm{pH}$ of biomass, biochars and derived ashes was measured in 1:20 (w/v) ratio of material to MilliQ water [30]. Ovendried samples were manually ground in a ceramic pot to pass through a $1 \mathrm{~mm}$ sieve. The samples and MilliQ water were mixed in conical flasks. The flasks were shaken at 90 RPM on a mechanical shaker at room temperature for $1 \mathrm{~h}$. The suspensions were filtered through a Whatman No. 40 filter paper and the $\mathrm{pH}$ was measured using a glass-electrode $\mathrm{pH}$ meter $827 \mathrm{pH}$ Lab (Metrohm, Switzerland). The $\mathrm{pH}$ of biochar and ashes was measured in triplicates and average values are reported here.

\section{Content of Selected Plant Nutrients in Biomass, Biochar and Ashes}

Oven dried and ground substrates between 10 and $30 \mathrm{mg}$ were digested in $1.0 \mathrm{ml}$ of $15 \% \mathrm{H}_{2} \mathrm{O}_{2}$ and $2.5 \mathrm{ml}$ of $70 \% \mathrm{HNO}_{3}$ at $240^{\circ} \mathrm{C}$ and 200 bar in a pressurized microwave oven for $15 \mathrm{~min}$ (Ultrawave, Milestone Inc., Italy). Five hundred $\mu$ hydrofluoric acid was added after digestion and cooling, and the samples were left standing overnight. The solutions were diluted before final analysis by inductively coupled plasma optical emission spectrometry (ICP-OES, Agilent 5100, Agilent Technologies, Santa Clara, USA) for determination of Fe, K, Mg, P and Zn. Each material was tested in triplicate and the average values are reported here.

\section{Surface Area of Biochar and Ashes}

Brunauer-Emmett-Teller (BET) surface area of the biochar and ashes was measured using NOVAtouch LX2EN290 gas sorption analyzer (Quantachrome Instruments, USA). Samples were oven-dried and homogeneously ground to pass through a $1 \mathrm{~mm}$ sieve before testing. About $1.0 \mathrm{~g}$ sample was loaded for measurement. Prior to the analysis, the samples were degassed at $350{ }^{\circ} \mathrm{C}$ under vacuum for $4 \mathrm{~h}$. The BET surface area of each material was measured once. 


\section{Effect of P-Rich Biochar and Ashes on Available P of Agricultural Soils}

\section{Soil Incubation Experiment with P-Rich Biochar and Ashes}

The effect of thermally converted P-rich char/ashes on the available $\mathrm{P}$ of agricultural soil was tested in a short-term incubation experiment. Two different Danish soils were used for the experiment. Both were collected from the top soil layer of fields located at the University of Copenhagen's Experimental Farm Højbakkegård (Taastrup, Denmark). One soil type was classified as fine sand with $9.8 \%$ clay, $10.4 \%$ silt $44.9 \%$ fine sand and $32.3 \%$ coarse sand, the other one was a sandy loam with $16.5 \%$ clay, $17.1 \%$ silt, $27.5 \%$ fine sand and $27.2 \%$ coarse sand. After collection, the soils were airdried and stored at room temperature. Prior to the incubation experiment, soils were sieved $(2 \mathrm{~mm})$. For the incubation, four P-rich biomasses (SS, BF, CM, PM), their derived biochars and the two ashes produced from post-process oxidation and steam gasification of the biochars were oven-dried, ground manually in a mortar, sieved through a $0.25 \mathrm{~mm}$ sieve and thoroughly mixed into $50 \mathrm{~g}(\mathrm{dw})$ of each of the two soils at a rate of $80 \mathrm{mg} \mathrm{P} / \mathrm{kg}$ soil. Blank soil (controls) and soil mixed with Triple Super Phosphate (TSP) fertilizer at the same $\mathrm{P}$ level were included for comparison. The samples were watered with MilliQ water to $50 \%$ WHC of the soils. The containers were incubated in a climate chamber at $20{ }^{\circ} \mathrm{C}$ for 3 weeks. The moisture content of the containers was adjusted by adding water on a weekly basis. After incubation, water-extractable $\mathrm{P}$ was determined at a 1:60 soil:MilliQ water ratio. The tubes with the solution were shaken for 1 h, centrifuged ( $5 \mathrm{~min}, 5000 \times \mathrm{g}$ ) and the supernatant was filtered directly through a Whatman no. 5 filter paper. Water extractable $\mathrm{P}$ was analyzed by Flow Injection Analysis (FIA) (FIAstar 5000, Foss, Sweden). Each material was tested in triplicate and the average values are reported here.

\section{Effect of C-Rich Biochar on Soil Properties}

\section{Soil Incubation Experiment with C-Rich Biochar}

Two C-rich biochars, the wood chips biochar (WCB) and the wheat straw biochar (WSB) were mixed into the same soils separately as described above at different application rates to evaluate the effect of char concentration in the soil on selected soil properties. Air-dried and 2-mm sieved soil samples (50 g $\mathrm{dw}$ ) were filled into the plastic containers. Both biochars were ground manually in a mortar and were mixed into the soils at five different rates $(0.1,0.5,1.0,2.0,5.0 \mathrm{wt} \%)$. A blank control (0 wt $\%$ ) was added for comparison. The biochar application rate of $1.0 \mathrm{wt} \%$ would correspond to $28 \mathrm{t} / \mathrm{ha}$ considering a soil depth of $20 \mathrm{~cm}$ and soil bulk density of $1.4 \mathrm{~g} / \mathrm{cm}^{3}$. All treatments were prepared in triplicate, watered with MilliQ water to $100 \%$ WHC and placed inside the incubator for 4 weeks following the procedure described above. After the incubation, the soils were tested for selected properties in triplicate as described below.

\section{Soil Organic Matter}

Soil organic matter was determined via the loss-on-ignition method by burning the soil sample at $440{ }^{\circ} \mathrm{C}$ to constant weight following the standard soil testing procedures ASTM D 2974-87.

\section{Soil pH}

Five grams of air-dry soil were weighed into a $50 \mathrm{ml}$ falcon tube and $25 \mathrm{ml}$ of MilliQ water was added to the tube. The samples were shaken for $1 \mathrm{~h}$ using a mechanical shaker. After shaking for $1 \mathrm{~h}$, the tubes were left standing for $1 \mathrm{~h}$ and the $\mathrm{pH}$ was then measured immediately using a glass electrode $\mathrm{pH}$ meter after having briefly shaken the tubes by hand.

\section{Soil Cation Exchange Capacity}

Soil CEC was measured with ammonium acetate. Ten grams of air-dried soil samples were weighed into $50 \mathrm{ml}$ Falcon tubes. Thirty milliliters of $1 \mathrm{M}$ ammonium acetate $(\mathrm{pH} 7)$ were added, samples were shaken for $2 \mathrm{~min}$ and then placed into the refrigerator overnight $(18 \mathrm{~h})$. Subsequently, the samples were shaken again for $2 \mathrm{~min}$ and centrifuged at $5000 \times \mathrm{g}$ for $5 \mathrm{~min}$ and the supernatant was discarded. Again, $30 \mathrm{ml}$ ammonium acetate was added, shaken for $2 \mathrm{~min}$, centrifuged and the supernatant was discarded. This step was carried out for four times in total. Then, $20 \mathrm{ml}$ ethanol were added to the tubes, tubes were shaken for $2 \mathrm{~min}$, centrifuged at $5000 \times \mathrm{g}$ for $5 \mathrm{~min}$ and the supernatants were discarded. Samples were washed with ethanol four times. Subsequently, $20 \mathrm{ml}$ of $1 M$ $\mathrm{KCl}$ were added to each sample, tubes were shaken for $2 \mathrm{~min}$ and centrifuged at $5000 \times g$ for $5 \mathrm{~min}$. The supernatants were filtered into a $100 \mathrm{ml}$ volumetric flask using Whatman no.5 filter paper. This step was repeated four times in total. The flask was filled up to the volume $(100 \mathrm{ml})$. A $20 \mathrm{ml}$ subsample was taken and placed in the refrigerator prior to analysis for ammonium $\left(\mathrm{NH}_{4}-\mathrm{N}\right)$ on the FIA. The following equation was used for the calculation of CEC:

$C E C\left(\frac{\mathrm{cmol}}{\mathrm{kg}}\right)=C E C\left(\frac{\mathrm{meq}}{100 \mathrm{~g}}\right)=\left(\frac{\mathrm{mg} \mathrm{NH}_{4}-\mathrm{N}}{\mathrm{L}}\right) \times\left(\frac{0.1 \mathrm{~L}}{10 \mathrm{~g} \mathrm{soil}}\right) \times\left(\frac{1 \mathrm{meq} \mathrm{NH}_{4}-\mathrm{N}}{14 \mathrm{mg} \mathrm{NH}_{4}-\mathrm{N}}\right) \times 100$ 


\section{Soil Water Holding Capacity}

A known amount of air-dried soil was completely saturated with MilliQ water in a glass beaker. The saturated soil samples were carefully transferred onto a Buchner funnel lined with Whatman no. 5 filter paper. The funnel was covered from the top to minimize the evaporation loss and the samples were allowed to drain freely until the last drop had drained. The WHC was calculated by weighing the wetted soil, deducting the known weight of the air-dried soil and adjusting for the weight of the filter paper.

\section{Statistical Analyses}

A one-way ANOVA with post hoc mean separation based on Tukey's test was applied to assess the difference in the means of different treatments. The statistical analyses were conducted at 95\% confidence level $(\mathrm{P}<0.05)$ using SPSS13.0 (Chicago, IL, USA) software.

\section{Results}

\section{Yield of Biochar and Derived Ashes}

As expected, thermal treatments of the organic secondary resources (SS, BF, CM, PM) gave higher yields of biochar, oxidation or steam gasification ashes than those of the primary biomass fuels (WC, WS) (Fig. 1). Biochar mass yields of $54 \%, 46 \%, 38 \%$ and $46 \%$ on dry basis were obtained from SS, BF, CM and PM, respectively. In case of primary biomass fuels, biochar yields of $25 \%$ and $26 \%$ from WC and WS, respectively, were obtained. The same trend was observed for product yields from char oxidation and steam

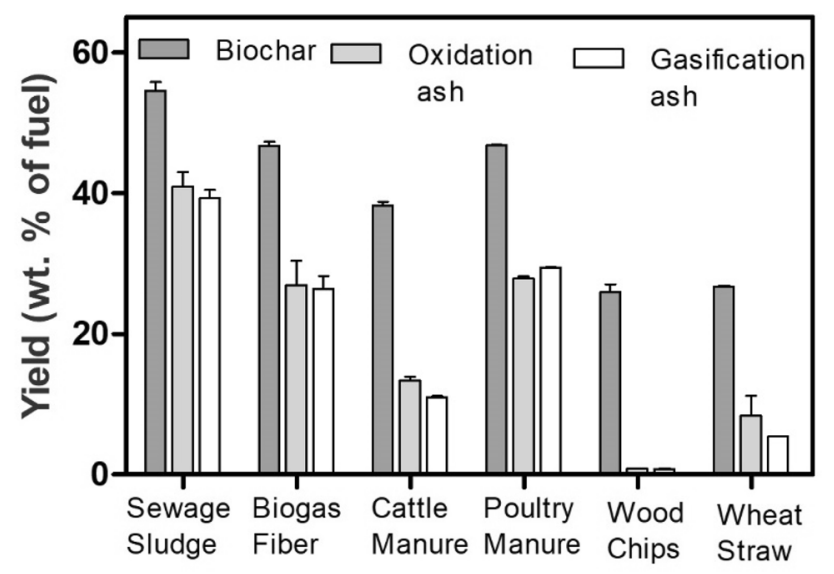

Fig. 1 Mass yield of biochars and ashes produced from different secondary and primary biomasses (Error bars represent maximum and minimum yields, $\mathrm{n}=3$ ) gasification post-processing, where the highest yields of $41 \%$ and $39 \%$ were recovered from the SS char oxidation and steam gasification, respectively. Post-processing of BF and PM resulted in very similar ash yields (26\% and 29\%), which were much lower than the ash yields obtained from SS. However, BF and PM ash yields were higher than those obtained from primary biomass fuels such as WC and WS ( $0.8 \%$ and $8 \%$, respectively). CM produced ash yields in between the secondary and the primary biomass fuels $(13 \%$ and $11 \%$ for char oxidation and steam gasification, respectively) (Fig. 1).

\section{Characterization of Biochar and Derived Ashes}

\section{Proximate and Ultimate Analysis}

Proximate and ultimate analyses results from the biomass fuels and their derived biochars and ashes are shown in Tables 1 and 2.

The $\mathrm{C}$ content in the biochar obtained from high-ash feedstock decreased by $27 \%$ (SS), 15\% (BF) and 19\% (CM) compared to the oven-dried organic materials. In contrast, the $\mathrm{C}$ content in the biochar derived from low-ash feedstock increased by $82 \%$ (WC) and 52\% (WS) compared to the original feedstock (Table 2). The N content decreased up to 50\% in the resulting biochars compared to the original feedstock. The S content in sewage sludge biochar (SSB) decreased from $3.9 \%$ (dry sludge) to $2.3 \%$ (biochar) while it decreased to negligible levels in all other biochar- and ash products.

\section{$\mathrm{pH}$ of Biochar and Ashes}

Table 3 presents the $\mathrm{pH}$ in MilliQ water of original biomass, biochars and ashes. The dry SS (5.62) and dry WC (4.39) had an acidic $\mathrm{pH}$, while the dry PM (9.44) had an alkaline $\mathrm{pH}$. The remaining three biomasses i.e. BF, CM and WS had a neutral $\mathrm{pH}$. The $\mathrm{pH}$ of all biochars increased as compared to their original biomass. Thermal processing had a clear effect on the $\mathrm{pH}$ of the resulting biochar or ash. As shown in Table 3, the general trend was as follows: $\mathrm{pH}$ of pyrolysis char $<\mathrm{pH}$ of oxidation ash $<\mathrm{pH}$ of gasification ash.

\section{Content of Selected Plant Nutrients in Biochar and Ashes}

Dry SS had higher contents of some essential plant nutrients including $\mathrm{Fe}, \mathrm{P}$ and $\mathrm{Zn}$ compared to the other biomasses. However, a higher $\mathrm{K}$ content was observed in dry manures and dry straw (Table 4). The concentration of most of the essential elements increased because of the thermal treatments, following this general trend oxidation ash $>$ gasification ash $>$ biochar $>$ untreated biomass. The highest increase in $\mathrm{P}$ concentration was found for $\mathrm{BF}$, where the $\mathrm{P}$ content increased 5, 4.8 and 3 times during pyrolysis + oxidation, 
Table 1 Proximate analysis of the biomass fuels, biochar and derived ashes (Mean \pm standard deviation of triplicate measurements)

\begin{tabular}{|c|c|c|c|}
\hline Sample & Moisture (\%) & Organic matter (\% db.) & Ash content $(\% \mathrm{db})$. \\
\hline Sewage sludge & $29.0 \pm 1.13$ & $57.00 \pm 3.25$ & $43.0 \pm 6.20$ \\
\hline Biochar & $3.22 \pm 0.12$ & $32.00 \pm 2.7$ & $68.0 \pm 3.40$ \\
\hline Oxidation ash & $2.10 \pm 0.07$ & $6.00 \pm 0.56$ & $94.0 \pm 5.26$ \\
\hline Gasification ash & $1.70 \pm 0.01$ & $2.00 \pm 0.13$ & $98.0 \pm 4.89$ \\
\hline Biogas fiber & $70.40 \pm 1.89$ & $71.30 \pm 1.50$ & $28.70 \pm 3.50$ \\
\hline Biochar & $6.83 \pm 0.29$ & $36.93 \pm 2.26$ & $63.07 \pm 2.00$ \\
\hline Oxidation ash & $3.56 \pm 0.23$ & $5.60 \pm 0.30$ & $94.40 \pm 4.83$ \\
\hline Gasification ash & $5.46 \pm 0.24$ & $4.90 \pm 0.50$ & $95.10 \pm 2.50$ \\
\hline Cattle manure & $76.36 \pm 1.71$ & $86.09 \pm 1.75$ & $13.91 \pm 1.80$ \\
\hline Biochar & $4.65 \pm 0.41$ & $64.10 \pm 3.20$ & $35.90 \pm 4.10$ \\
\hline Oxidation ash & $3.15 \pm 0.23$ & $9.46 \pm 0.80$ & $90.54 \pm 3.30$ \\
\hline Gasification ash & $3.67 \pm 0.38$ & $6.00 \pm 0.48$ & $94.00 \pm 6.00$ \\
\hline Poultry manure & $71.70 \pm 1.10$ & $67.46 \pm 4.80$ & $32.54 \pm 4.10$ \\
\hline Biochar & $3.95 \pm 0.61$ & $40.00 \pm 3.15$ & $60.00 \pm 4.00$ \\
\hline Oxidation ash & $2.45 \pm 0.72$ & $11.00 \pm 1.22$ & $89.00 \pm 3.70$ \\
\hline Gasification ash & $2.25 \pm 0.16$ & $4.20 \pm 0.82$ & $95.80 \pm 6.21$ \\
\hline Woodchips & $8.22 \pm 0.64$ & $99.2 \pm 5.28$ & $0.84 \pm 0.10$ \\
\hline Biochar & $5.37 \pm 0.29$ & $96.95 \pm 4.50$ & $3.05 \pm 0.30$ \\
\hline Oxidation ash & $3.21 \pm 0.16$ & $26.0 \pm 2.20$ & $74.00 \pm 2.50$ \\
\hline Gasification ash & $2.70 \pm 0.08$ & $17.0 \pm 4.16$ & $83.00 \pm 2.10$ \\
\hline Wheat straw & $8.41 \pm 0.57$ & $95.0 \pm 6.61$ & $4.97 \pm 1.10$ \\
\hline Biochar & $3.75 \pm 0.16$ & $81.4 \pm 5.50$ & $18.62 \pm 3.20$ \\
\hline Oxidation ash & $4.81 \pm 0.29$ & $22.0 \pm 4.20$ & $78.00 \pm 5.30$ \\
\hline Gasification ash & $4.32 \pm 0.23$ & $13.0 \pm 3.10$ & $87.00 \pm 2.30$ \\
\hline
\end{tabular}

pyrolysis + steam gasification and pyrolysis without postprocess biochar treatment, respectively (Table 4).

\section{Surface Area of Biochar and Ashes}

The BET surface area of several produced biochars like SSB, CMB and WSB was almost the same (50 to $52 \mathrm{~m}^{2} / \mathrm{g}$ ) while the poultry manure biochar (PMB) had the lowest surface area $\left(12.4 \mathrm{~m}^{2} / \mathrm{g}\right)$ and the WCB had the highest surface area $\left(333.8 \mathrm{~m}^{2} / \mathrm{g}\right)$. Four of the six samples (SS, PM, WC and $\mathrm{CM}$ ) exhibited a similar trend among the different substrate categories with untreated biochar having the highest surface area, followed by gasified ash and oxidation ash with the lowest surface area. However for two of the samples -BF and WS-, the surface area of the gasified ash was much higher (factor 3-4) than that of the untreated biochar (Table 5).

\section{Effect of P-Rich Biochars and Ashes on Available P of Agricultural Soils}

The produced materials showed similar effects in both soils, with greater differences between treatments in the sandy loam. All materials derived from sewage sludge resulted in the same level of available $\mathrm{P}$ as in the nonamended control soils (Fig. 2). Among the feedstock materials, $\mathrm{BF}$ and $\mathrm{CM}$ resulted in the highest levels of available $\mathrm{P}$. The addition of dry BF resulted in significantly more available $\mathrm{P}$ than their derived biochars and ashes in the sandy soil, while there was no significant difference between the products from BF in the sandy loam. However, all BF products except the untreated biochar in the sandy loam significantly increased the P levels compared to the unfertilized control. That was also true for the materials from CM that performed similarly. However, in case of sandy loam soil, $\mathrm{P}$ availability was significantly decreased in CM oxidation ash compared to the feedstock material. In contrast, in gasification ashes derived from PM, more available $\mathrm{P}$ was measured than for the treatment receiving the dry $\mathrm{PM}$ itself, although the differences were not statistically significant. Except for PM oxidation ash, both oxidation and gasification ashes derived from BF, CM and $\mathrm{PM}$ biochar significantly $(\mathrm{P}<0.05)$ increased available $\mathrm{P}$ in both soils, while only the untreated chars from CM (both soils) and BF (sandy soil) showed a P fertilizer effect. Generally, the gasification ashes showed a better performance than the oxidation ashes which again was found to be better than the untreated biochar. However, there were two exceptions to the general pattern; (i) for SS only, the water-extractable P in soil was slightly, but not significantly higher after addition of oxidation ash 
Table 2 Ultimate analysis (wt\%) of the biomass fuels, biochar and ashes (Mean \pm standard deviation of triplicate measurements, nd $=$ not detected)

\begin{tabular}{|c|c|c|c|c|c|c|c|}
\hline Sample & $\mathrm{C}$ & $\mathrm{H}$ & $\mathrm{N}$ & $\mathrm{O}$ & $\mathrm{S}$ & $\mathrm{O}: \mathrm{C}$ & $\mathrm{H}: \mathrm{C}$ \\
\hline Sewage sludge & $29.9 \pm 3.20$ & $4 \pm 0.21$ & $4.8 \pm 0.24$ & $14.7 \pm 1.75$ & $3.6 \pm 0.63$ & $0.37 \pm 0.0$ & $1.60 \pm 0.09$ \\
\hline Biochar & $21.7 \pm 2.10$ & $0.7 \pm 0.08$ & $1.8 \pm 0.30$ & $4.9 \pm 0.38$ & $2.9 \pm 0.36$ & $0.17 \pm 0.0$ & $0.38 \pm 0.01$ \\
\hline Oxidation ash & $0.5 \pm 0.07$ & nd & $0.1 \pm 0.08$ & $3.5 \pm 0.58$ & $0.7 \pm 0.13$ & $5.24 \pm 0.12$ & 0.00 \\
\hline Gasification ash & $0.35 \pm 0.03$ & nd & nd & nd & nd & nd & 0.00 \\
\hline Biogas fiber & $37.9 \pm 11.50$ & $5.4 \pm 0.21$ & $5.5 \pm 1.02$ & $17.6 \pm 2.24$ & $1 \pm 0.31$ & $0.35 \pm 0.01$ & $1.68 \pm 0.08$ \\
\hline Biochar & $31.9 \pm 2.60$ & $0.8 \pm 0.03$ & $2.8 \pm 0.68$ & $4.3 \pm 0.85$ & $0.3 \pm 0.07$ & $0.03 \pm 0.01$ & $0.23 \pm 0.01$ \\
\hline Oxidation ash & $3.4 \pm 0.16$ & nd & $0.4 \pm 0.09$ & $3.3 \pm 0.21$ & nd & $1.10 \pm 0.01$ & 0.00 \\
\hline Gasification ash & $0.3 \pm 0.08$ & nd & nd & $1.1 \pm 0.94$ & nd & nd & 0.00 \\
\hline Cattle manure & $39.1 \pm 2.25$ & $5.5 \pm 0.07$ & $2.9 \pm 0.45$ & $18.4 \pm 1.60$ & $5.4 \pm 0.51$ & $0.56 \pm 0.02$ & $1.46 \pm 0.08$ \\
\hline Biochar & $31.6 \pm 4.13$ & $0.6 \pm 0.11$ & $2.8 \pm 0.37$ & $1.4 \pm 0.77$ & $0.5 \pm 0.07$ & $0.10 \pm 0.01$ & $0.29 \pm 0.12$ \\
\hline Oxidation ash & $1.3 \pm 0.10$ & 0 & $0.1 \pm 0.02$ & $1.9 \pm 0.16$ & $1.1 \pm 0.073$ & $2.60 \pm 0.38$ & nd \\
\hline Gasification ash & $12 \pm 1.45$ & 0 & $0.3 \pm 0.01$ & 0 & $0.1 \pm 0.04$ & $5.22 \pm 1.12$ & nd \\
\hline Poultry manure & $44.1 \pm 3.00$ & $5.4 \pm 0.66$ & $2.2 \pm 0.31$ & $33.2 \pm 3.37$ & $1.3 \pm 0.16$ & $0.35 \pm 0.03$ & $1.70 \pm 0.01$ \\
\hline Biochar & $53.1 \pm 3.25$ & $1.3 \pm 0.61$ & $1.7 \pm 0.73$ & $7.4 \pm 1.28$ & $0.5 \pm 0.03$ & $0.10 \pm 0.01$ & $0.30 \pm 0.01$ \\
\hline Oxidation ash & $2.1 \pm 0.80$ & nd & $0.1 \pm 0.05$ & $7 \pm 1.77$ & $0.3 \pm 0.08$ & $0.73 \pm 0.01$ & nd \\
\hline Gasification ash & $0.7 \pm 0.03$ & nd & $0.4 \pm 0.02$ & $4.9 \pm 1.25$ & nd & $2.44 \pm 1.76$ & nd \\
\hline Woodchips & $47.0 \pm 2.04$ & $6.3 \pm 2.08$ & $0.27 \pm 0.03$ & $37.7 \pm 4.00$ & $1.8 \pm 0.89$ & $0.60 \pm 0.04$ & $1.59 \pm 0.46$ \\
\hline Biochar & $86.1 \pm 3.36$ & $2.9 \pm 0.44$ & $1.37 \pm 0.21$ & $2.9 \pm 0.27$ & $0.5 \pm 0.15$ & $0.03 \pm 0.00$ & $0.40 \pm 0.05$ \\
\hline Oxidation ash & $7.2 \pm 2.1$ & nd & $0.2 \pm 0.02$ & $16.2 \pm 3.04$ & nd & $1.73 \pm 0.19$ & nd \\
\hline Gasification ash & $2.7 \pm 0.35$ & $0.7 \pm 0.8$ & nd & $11.7 \pm 1.51$ & $0.2 \pm 0.02$ & $3.25 \pm 0.00$ & $3.10 \pm 0.02$ \\
\hline Wheat straw & $48.1 \pm 5.10$ & $7.3 \pm 2.20$ & $2.2 \pm 0.37$ & $32.8 \pm 2.30$ & $4.6 \pm 0.90$ & $0.51 \pm 0.02$ & $1.79 \pm 0.36$ \\
\hline Biochar & $73 \pm 4.15$ & $1.9 \pm 0.50$ & $1.9 \pm 0.28$ & $4.6 \pm 0.67$ & nd & $0.05 \pm 0.00$ & $0.31 \pm 0.06$ \\
\hline Oxidation ash & $1.3 \pm 0.06$ & nd & $0.1 \pm 0.01$ & $11.1 \pm 1.82$ & $0.3 \pm 0.10$ & $6.39 \pm 0.076$ & nd \\
\hline Gasification ash & $15.6 \pm 1.20$ & $0.1 \pm 0.01$ & nd & nd & nd & nd & $0.08 \pm 00.00$ \\
\hline
\end{tabular}

Table $3 \mathrm{pH}$ of the biomass, biochar and ashes in water (Mean \pm standard deviations of three measurements)

\begin{tabular}{lrlc}
\hline Sample & \multicolumn{1}{l}{$\mathrm{pH}$} & Sample & $\mathrm{pH}$ \\
\hline Sewage sludge & $5.62 \pm 0.03$ & Poultry manure & $9.44 \pm 0.04$ \\
Biochar & $8.59 \pm 0.02$ & Biochar & $10.67 \pm 0.02$ \\
Oxidation ash & $9.03 \pm 0.03$ & Oxidation ash & $11.88 \pm 0.045$ \\
Gasification ash & $11.66 \pm 0.03$ & Gasification ash & $12.64 \pm 0.01$ \\
Biogas fiber & $7.63 \pm 0.02$ & Woodchips & $4.39 \pm 0.00$ \\
Biochar & $10.38 \pm 0.01$ & Biochar & $9.00 \pm 0.01$ \\
Oxidation ash & $10.60 \pm 0.02$ & Oxidation ash & $12.08 \pm 0.01$ \\
Gasification ash & $11.73 \pm 0.01$ & Gasification ash & $12.39 \pm 0.01$ \\
Cattle manure & $7.85 \pm 0.01$ & Wheat straw & $7.38 \pm 0.04$ \\
Biochar & $10.63 \pm 0.04$ & Biochar & $10.02 \pm 0.025$ \\
Oxidation ash & $11.48 \pm 0.01$ & Oxidation ash & $11.56 \pm 0.01$ \\
Gasification ash & $12.49 \pm 0.01$ & Gasification ash & $11.71 \pm 0.015$ \\
\hline
\end{tabular}

than gasification ash in both soils (Fig. 2), and (ii) for CM only, oxidizing the biochar reduced $\mathrm{P}$ plant availability compared to the untreated biochar. Among all thermally treated products of the four P-rich secondary residues, the CM gasification ash was found most effective as it increased the sandy loam soil's available P from 2.33 to $17.21 \mathrm{mg} / \mathrm{kg}$, which was $22 \%$ higher than that of TSP fertilizer $(14 \mathrm{mg} / \mathrm{kg})$.

\section{Effect of P-Rich Biochar and Ashes on Soil pH}

During the 3 weeks-incubation, the TSP fertilizer did not change the soil $\mathrm{pH}$, but some of the other substrates caused small changes in the $\mathrm{pH}$ of both soils (Fig. 3). In the sandy soil, no effect was observed from the materials derived from $\mathrm{SS}$ and $\mathrm{BF}$, but they significantly increased the $\mathrm{pH}$ in the sandy loam soil. The biochar and ashes derived from CM and $\mathrm{PM}$ were found to increase the soil $\mathrm{pH}$ to a greater extent than those derived from BF or SS. In general, the maximum soil $\mathrm{pH}$ increase was observed for application of gasification ash with the highest increase being $0.78 \mathrm{pH}$ units for the cattle manure gasification ash in the sandy loam.

\section{Effect of C-Rich Biochar on Properties of two Different Agricultural Soils}

As expected, biochar application increased soil organic matter (SOM) after short-term incubation. A statistically 
Table 4 Selected plant nutrients $(\mathrm{g} / \mathrm{kg})$ in the biochar and ashes (Mean \pm standard deviations of triplicate values, $\mathrm{nd}=$ not determined)

\begin{tabular}{lcrrrl}
\hline Sample & Fe & \multicolumn{1}{l}{$\mathrm{K}$} & $\mathrm{P}$ & $\mathrm{Zn}$ \\
\hline Sewage sludge & $76.22 \pm 4.14$ & $5.01 \pm 0.04$ & $5.17 \pm 0.02$ & $32.92 \pm 0$ & $0.52 \pm 0.22$ \\
Biochar & $118.05 \pm 0.96$ & $8.79 \pm 0.27$ & $9.11 \pm 0.76$ & $54.20 \pm 2.18$ & $1.12 \pm 0.04$ \\
Oxidation ash & $130.27 \pm 5.06$ & $12.23 \pm 0.44$ & $13.61 \pm 0.19$ & $70.68 \pm 3.91$ & $1.99 \pm 0.07$ \\
Gasification ash & $132.58 \pm 11.21$ & $12.39 \pm 0.05$ & $14.00 \pm 0.11$ & $63.29 \pm 3.90$ & $2.01 \pm 0.03$ \\
Biogas fiber & $3.03 \pm 0.04$ & $11.50 \pm 0.42$ & $13.43 \pm 0.20$ & $22.45 \pm 1.63$ & $0.29 \pm 0.001$ \\
Biochar & $7.22 \pm 0.05$ & $26.82 \pm 0.81$ & $46.76 \pm 2.25$ & $67.95 \pm 1.78$ & $0.76 \pm 0.03$ \\
Oxidation ash & $12.74 \pm 0.44$ & $47.80 \pm 1.28$ & $76.10 \pm 2.74$ & $113.40 \pm 2.15$ & $\mathrm{nd}$ \\
Gasification ash & $12.72 \pm 0.22$ & $41.60 \pm 0.28$ & $71.40 \pm 1.24$ & $106.20 \pm 0.60$ & $1.21 \pm 0.01$ \\
Cattle manure & $1.19 \pm 0.22$ & $10.20 \pm 1.33$ & $3.60 \pm 0.34$ & $4.00 \pm 0.39$ & $0.12 \pm 0.01$ \\
Biochar & $2.74 \pm 0.08$ & $24.30 \pm 0.27$ & $11.60 \pm 0.12$ & $11.70 \pm 0.09$ & $0.34 \pm 0.01$ \\
Oxidation ash & $6.54 \pm 0.17$ & $72.00 \pm 2.59$ & $32.00 \pm 0.80$ & $52.40 \pm 2.34$ & $\mathrm{nd}$ \\
Gasification ash & $8.93 \pm 1.07$ & $73.60 \pm 2.96$ & $37.80 \pm 1.95$ & $38.90 \pm 2.01$ & $1.22 \pm 0.05$ \\
Poultry manure & $2.20 \pm 1.29$ & $23.60 \pm 0.52$ & $8.10 \pm 1.13$ & $26.20 \pm 1.57$ & $0.46 \pm 0.02$ \\
Biochar & $4.06 \pm 2.34$ & $43.60 \pm 4.72$ & $11.60 \pm 1.14$ & $40.50 \pm 4.18$ & $0.89 \pm 0.11$ \\
Oxidation ash & $8.34 \pm 0.31$ & $62.20 \pm 1.15$ & $27.80 \pm 1.71$ & $57.20 \pm 0.03$ & $0.78 \pm 0.01$ \\
Gasification ash & $7.49 \pm 0.28$ & $72.20 \pm 0.16$ & $22.20 \pm 0.57$ & $72.30 \pm 1.54$ & $0.85 \pm 0.08$ \\
Woodchips & $0.27 \pm 0.20$ & $0.58 \pm 0$ & $0.12 \pm 0.02$ & $0.19 \pm 0.09$ & $0.01 \pm 0$ \\
Biochar & $0.18 \pm 0.04$ & $2.52 \pm 0.02$ & $0.56 \pm 0$ & $0.30 \pm 0.02$ & $0.05 \pm 0$ \\
Oxidation ash & $6.28 \pm 0.16$ & $78.98 \pm 0.68$ & $18.29 \pm 0.12$ & $11.27 \pm 0.39$ & $0.81 \pm 0.03$ \\
Gasification ash & $29.01 \pm 2.84$ & $59.71 \pm 3.90$ & $20.02 \pm 0.48$ & $10.25 \pm 0.39$ & $0.80 \pm 0.01$ \\
Wheat straw & $1.77 \pm 0.16$ & $10.20 \pm 0.09$ & $1.40 \pm 0.16$ & $2.00 \pm 0.18$ & $0.35 \pm 0.04$ \\
Biochar & $0.23 \pm 0.03$ & $36.00 \pm 0.40$ & $2.30 \pm 0.03$ & $4.20 \pm 0.06$ & $0.15 \pm 0.01$ \\
Oxidation ash & $2.96 \pm 0$ & $193.70 \pm 2.06$ & $11.80 \pm 0.25$ & $22.00 \pm 0.51$ & $\mathrm{nd}$ \\
Gasification ash & $2.28 \pm 0.17$ & $173.00 \pm 3.73$ & $11.50 \pm 0.23$ & $20.70 \pm 0.33$ & $0.16 \pm 0.01$ \\
\hline & & & & & \\
& & & & \\
& & & &
\end{tabular}

Table 5 BET surface area of the biochar and ashes. (Single measurements, nd = not determined)

\begin{tabular}{|c|c|c|c|}
\hline Sample & $\begin{array}{l}\text { Surface } \\
\text { area }\left(\mathrm{m}^{2} / \mathrm{g}\right)\end{array}$ & Sample & $\begin{array}{l}\text { Surface area } \\
\left(\mathrm{m}^{2} / \mathrm{g}\right)\end{array}$ \\
\hline Sewage sludge: & & Poultry manure: & \\
\hline Biochar & 52.8 & Biochar & 12.4 \\
\hline Oxidation ash & 16.8 & Oxidation ash & 5.0 \\
\hline Gasification ash & 24.4 & Gasification ash & 6.7 \\
\hline Biogas fiber: & & Woodchips: & \\
\hline Biochar & 74.3 & Biochar & 333.8 \\
\hline Oxidation ash & 13.9 & Oxidation ash & 5.9 \\
\hline Gasification ash & 192.5 & Gasification ash & nd \\
\hline Cattle manure: & & Wheat straw: & \\
\hline Biochar & 50.7 & Biochar & 52.5 \\
\hline Oxidation ash & 8.7 & Oxidation ash & 6.4 \\
\hline Gasification ash & 20.7 & Gasification ash & 208.2 \\
\hline
\end{tabular}

significant increase (24\%) in SOM was observed after the addition of $1 \mathrm{wt} \%$ biochar in the sandy soil, while in the sandy loam, a significant increase (18\%) was noted with an even lower application rate $(0.5 \mathrm{wt} \%)$ of WCB (Table 6$)$. However, there were no differences in the effect of the two different types of biochars (WCB and WSB) on SOM content.

The addition of biochars from lignocellulosic materials (WC \& WS) increased the $\mathrm{pH}$ of both soils proportional to the application rates. A significant increase in the soil $\mathrm{pH}$ was observed after the addition of $1 \mathrm{wt} \%$ biochar and it was further significantly increased with increasing biochar levels of 2 and $5 \mathrm{wt} \%$ (Table 6). The WSB had a stronger increasing effect on the soil $\mathrm{pH}$, but the effect was most pronounced as well as most consistent in the sandy soil.

The cation exchange capacity (CEC) of both soils increased with the addition of the two C-rich biochars (Table 6). The sandy soil had a lower CEC $(4.68 \mathrm{cmol} / \mathrm{kg})$ which was increased by $36 \%, 42 \%$ and $46 \%(\mathrm{P}<0.05)$ with WCB applied at $0.5 \mathrm{wt} \%, 1 \mathrm{wt} \%$ and $2 \mathrm{wt} \%$, respectively. However, the effect was reduced to a $24 \%(\mathrm{P}<0.05)$ increase at maximum biochar application rate of $5 \mathrm{wt} \%$ compared to the control. The WSB had a significant $(\mathrm{P}<0.05)$ positive effect on the CEC of sandy soil only at an application rate of $2 \mathrm{wt} \%$. The same trend on the sandy loam's CEC was observed. However, significant $(\mathrm{P}<0.05)$ effects were only observed at 1 and $2 \mathrm{wt} \%$ biochar application rate (Table 6) in this soil. 


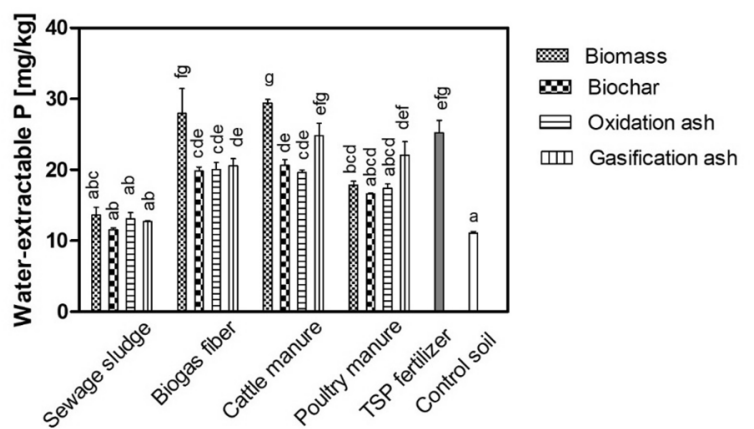

(A) Fine Sand

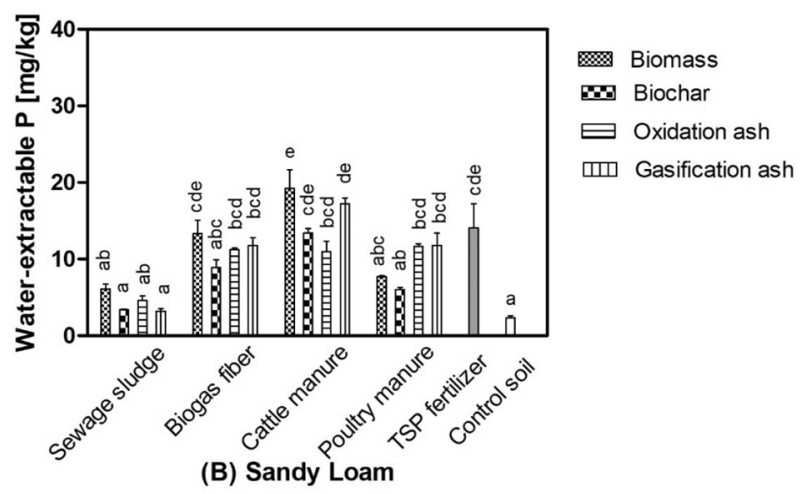

Fig. 2 Effect of different P-rich biomass, biochar and ashes on available P of the sandy soil (A) and sandy loam (B). Error bars show standard deviations and the bars with different letters are significantly $(\mathrm{P}<0.05)$ different. The treatments-Sewage sludge biochar and gasification ash in sandy soil (A) are two replicates

The soil water holding capacity (WHC) of both soils was increased with the addition of both biochars at an application rate of $1 \mathrm{wt} \%$ and above (Table 6). Maximum increase of the sandy soil's WHC was $27 \%(\mathrm{P}<0.05)$ at $5 \mathrm{wt} \%$ application rate. In the case of the sandy loam, the effect was lower $(20 \%)(\mathrm{P}<0.05)$ at the same biochar application rates. Regarding the two different types of biochar, WSB amendment resulted in a slightly higher increase in WHC of the soils than WCB (Table 6).

\section{Discussion}

The yield of biochar and derived ash products was strongly related to the ash content in the organic resources. The yields were the highest in treatment of SS that also had a much higher ash content (43\%) compared with the remaining five biomass resources $(0.84-32.54 \%)$ (Table 1). Although the char oxidation was conducted at lower temperature $\left(550{ }^{\circ} \mathrm{C}\right)$ than the original pyrolysis, the oxidizing nature of the treatment reduced the absolute mass output substantially due to volatilization of $\mathrm{C}, \mathrm{H}, \mathrm{S}, \mathrm{O}$ and some $\mathrm{N}$ [31]. The yield of gasification ashes was even lower than the yield of oxidation

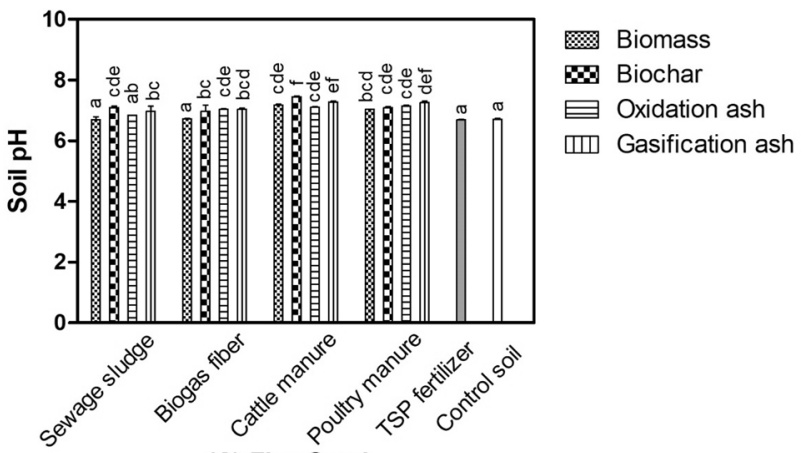

(A) Fine Sand

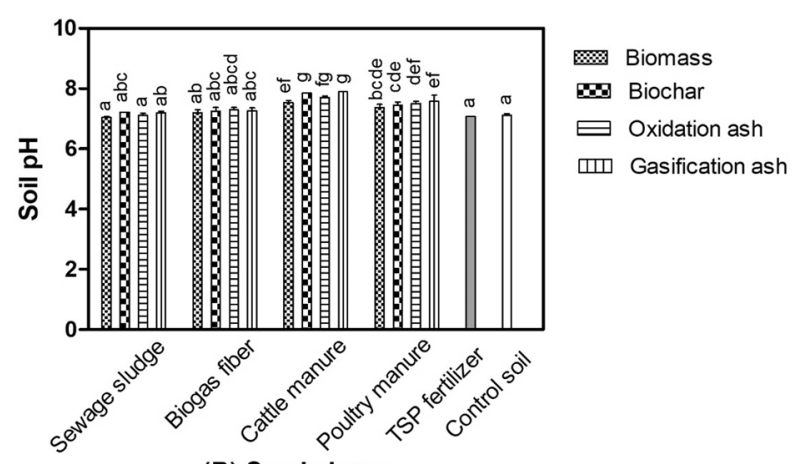

(B) Sandy Loam

Fig. 3 Effect of different P-rich biomass, biochar and ashes on soil $\mathrm{pH}$ of sandy soil (A) and sandy loam (B). Error bars show standard deviation and the bars with different letters are significantly $(\mathrm{P}<0.05)$ different

ashes (Fig. 1). The lower yield of solid ashes from thermal gasification is attributed to the higher thermal treatment temperature $\left(800^{\circ} \mathrm{C}\right)$. It is well-known that solid biochar or ash yield decreases with increasing the temperature as more $\mathrm{C}$ and mineral constituents are volatilized at higher temperatures [32]. All thermal treatments have the advantage of concentrating the macronutrients $\mathrm{P}, \mathrm{K}$ and $\mathrm{Mg}$ as well as the micronutrients $\mathrm{Fe}$ and $\mathrm{Zn}$. The increase range (54-202\%) in $\mathrm{P}$ content of six different biochars during pyrolysis (Table 4) is in line with the findings of previous studies by Frišták et al. [33] and Acelas et al. [34]. For WC and WS biomass, an increase of $57 \%$ and $110 \%$ in P content, respectively (Table 4), through the pyrolysis is also consistent with the findings of Colantoni et al. [35] who observed up to $194 \%$ increase in $\mathrm{P}$ content in agricultural residues biochar. The nutrient densification may improve transportability and support the development of new value-chains to increase nutrient recycling. However, all treatments-especially the postprocess char oxidation and char steam gasification processes also lead to substantial losses of the macro-nutrients $\mathrm{S}$ and $\mathrm{N}$ which should be considered when selecting biomass candidates for these treatments. The content of $\mathrm{N}$ in the different biochars was in accordance with findings in several previous studies Figueiredo et al. [36] and Wang et al. [37]. It may be 
Table 6 Effect of two different C-rich biochars on soil properties

\begin{tabular}{|c|c|c|c|c|c|}
\hline \multirow[t]{2}{*}{ Parameters } & \multirow{2}{*}{$\begin{array}{l}\text { Biochar applica- } \\
\text { tion rates (wt } \% \text { ) }\end{array}$} & \multicolumn{2}{|l|}{ Fine sand } & \multicolumn{2}{|l|}{ Sandy loam } \\
\hline & & WCB & WSB & WCB & WSB \\
\hline \multirow[t]{6}{*}{$\operatorname{SOM}(\%)$} & 0 & \multicolumn{2}{|c|}{$3.25 \pm 0.02$} & \multicolumn{2}{|c|}{$3.32 \pm 0.08$} \\
\hline & 0.1 & $3.23 \pm 0.17$ & $3.43 \pm 0.25$ & $3.33 \pm 0.15$ & $3.53 \pm 0.13$ \\
\hline & 0.5 & $3.37 \pm 0.22$ & $4.02 \pm 0.26$ & $3.94 \pm 0.05$ & $3.84 \pm 0.03$ \\
\hline & 1.0 & $3.83^{*} \pm 0.10$ & $4.05^{*} \pm 0.19$ & $4.09 \pm 0.24$ & $4.45 \pm 0.17$ \\
\hline & 2.0 & $4.65^{*} \pm 0.04$ & $4.45^{*} \pm 0.04$ & $4.74 \pm 0.03$ & $5.22 \pm 0.12$ \\
\hline & 5.0 & $6.36^{*} \pm 0.17$ & $6.32 * \pm 0.28$ & $7.06 \pm 0.14$ & $7.33 \pm 0.51$ \\
\hline \multirow[t]{6}{*}{ Soil pH } & 0 & \multicolumn{2}{|c|}{$6.57 \pm 0.03$} & \multicolumn{2}{|c|}{$7.04 \pm 0.00$} \\
\hline & 0.1 & $6.57 \pm 0.02$ & $6.57 \pm 0.04$ & $7.19 \pm 0.09$ & $7.05 \pm 0.02$ \\
\hline & 0.5 & $6.67 \pm 0.00$ & $6.70 \pm 0.04$ & $7.31 \pm 0.05$ & $7.15 \pm 0.02$ \\
\hline & 1.0 & $6.73 \pm 0.02 *$ & $6.96 \pm 0.05^{*}$ & $7.35 \pm 0.01$ & $7.35 \pm 0.02$ \\
\hline & 2.0 & $6.82 \pm 0.04^{*}$ & $7.36 \pm 0.04 *$ & $7.45 \pm 0.05$ & $7.26 \pm 0.01$ \\
\hline & 5.0 & $7.41 \pm 0.02 *$ & $8.21 \pm 0.03 *$ & $7.47 \pm 0.17$ & $7.71 \pm 0.05$ \\
\hline \multirow[t]{6}{*}{ Soil CEC $\left(\mathrm{cmol}^{+} / \mathrm{kg}\right)$} & 0 & \multicolumn{2}{|c|}{$4.68 \pm 0.28$} & \multicolumn{2}{|c|}{$7.05 \pm 0.13$} \\
\hline & 0.1 & $5.22 \pm 0.01$ & $5.04 \pm 0.74$ & $7.32 \pm 0.20$ & $7.21 \pm 1.64$ \\
\hline & 0.5 & $6.39 \pm 0.03^{*}$ & $5.74 \pm 0.17$ & $8.58 \pm 0.30$ & $8.41 \pm 0.81$ \\
\hline & 1.0 & $6.68 \pm 0.33^{*}$ & $6.36 \pm 0.15$ & $10.06 \pm 0.12 *$ & $10.14 \pm 0.12$ \\
\hline & 2.0 & $6.84 \pm 0.12 *$ & $6.55 \pm 0.86^{*}$ & $8.59 \pm 0.10^{*}$ & $11.83 \pm 0.45^{*}$ \\
\hline & 5.0 & $5.82 \pm 0.08^{*}$ & $5.66 \pm 0.09$ & $7.50 \pm 0.37$ & $8.59 \pm 0.63$ \\
\hline \multirow[t]{6}{*}{ WHC (\%) } & 0 & \multicolumn{2}{|c|}{$18 \pm 0.36$} & \multicolumn{2}{|c|}{$25 \pm 0.05$} \\
\hline & 0.1 & $19 \pm 0.34$ & $18 \pm 0.25$ & $25 \pm 0.05$ & $25 \pm 0.08$ \\
\hline & 0.5 & $19 \pm 0.250$ & $19 \pm 0.67$ & $25 \pm 0.19$ & $25 \pm 0.34$ \\
\hline & 1.0 & $19 \pm 0.155$ & $19 \pm 0.50$ & $25 \pm 0.19$ & $26 \pm 0.36^{*}$ \\
\hline & 2.0 & $20 \pm 0.20^{*}$ & $21 \pm 0.39 *$ & $26 \pm 0.13^{*}$ & $27 \pm 0.34 *$ \\
\hline & 5.0 & $23 \pm 0.17 *$ & $23 \pm 0.17 *$ & $29 \pm 0.29^{*}$ & $29 \pm 0.19 *$ \\
\hline
\end{tabular}

Mean \pm standard deviation, values with * are significantly $(\mathrm{P}<0.05)$ different from the control $(0 \%$ biochar application rate)

$S O M$ soil organic matter, $W C B$ woodchips biochar, $W S B$ wheat straw biochar, $C E C$ cation exchange capacity, $W H C$ water holding capacity of value to focus on candidates for pyrolysis with low $\mathrm{S}$ and $\mathrm{N}$ content to avoid losses, or to develop pre-treatment processes, e.g. anaerobic digestion and/or enhanced solid/liquid separation to redirect e.g. $\mathrm{N}$ and $\mathrm{P}$ to desired pools $[38,39]$. In the current study, poultry manure seems to be a promising candidate in this regard, as it has a very high $\mathrm{P}$ content - up to $4-7 \%$ in the biochar and resulting ashes, while the losses of $\mathrm{N}$ and $\mathrm{S}$ are among the smallest in the assessment due to low concentrations in the original substrate.

While nutrient concentration is highly important for distribution logistics and to build new value chains, the fertilizer quality, especially $\mathrm{P}$ plant availability, may be just as important for marketing the products. In this study, only a slight, insignificant increase in available $\mathrm{P}$ was observed in both soils after the addition of SS and the derived products. A varying $\mathrm{P}$ availability in SS has been reported and mostly been attributed to the $\mathrm{P}$ removal method applied in the wastewater treatment plant [40]. Furthermore, both tested soils had a $\mathrm{pH}$ that was close to neutral and are thus likely to respond less to $\mathrm{P}$ addition in sewage sludge compared to more acidic soils [41]. As for all other biomass materials, a reduction of $\mathrm{P}$ availability after pyrolysis was visible, which has also been observed in other studies. The extent of this reduction is often correlated with treatment temperature, feedstock composition and reaction atmosphere [9, 42]. A tendency for increased $\mathrm{P}$ availability after a post-process oxidation of the sludge-derived biochar was observed especially in the sandy loam, which is in accordance with results of Thomsen et al.[12] although in their study the SS material used had a much higher initial $\mathrm{P}$ availability, probably also due to a lower $\mathrm{pH}$ of the soil used. In case of SS thermal treatments, the post process oxidation seemed to be more effective in increasing the $\mathrm{P}$ fertilizer value than the postprocess steam gasification (Fig. 2). However, this pattern was largely inverted for the other P-rich substrates where the general trend was that steam gasification of char resulted in the highest $\mathrm{P}$ plant availability, although differences were often not statistically different. The differences between the biomass materials indicate that the optimal post-process to increase $\mathrm{P}$ availability is related to prevalent $\mathrm{P}$ species in the 
material, as it was e.g. proposed by Thomsen et al. [9] that the increased $\mathrm{P}$ availability after oxidation was at least partly due to the oxidation of Fe-phosphates to more soluble components. The low initial $\mathrm{P}$ availability of PM can probably be attributed to its high content of phytate which is converted to inorganic $\mathrm{P}$ forms such as apatite and $\mathrm{Mg}$-phosphates through thermal processing [43]. Qian et al. [44] found an increased $\mathrm{P}$ availability in a biochar from non-chemically treated sludge after a low-temperature steam activation and attributed the effect to the hydrolyzation of insoluble condensed polyphosphates in the biochar to soluble $\mathrm{P}$ forms. However, also the reduction of the $\mathrm{C}$ content, that was even more pronounced after gasification than after oxidation in most of the materials, could increase $\mathrm{P}$ availability, as the aromatic $\mathrm{C}$ structures in biochar are suggested to physically inhibit $\mathrm{P}$ dissolution in biochar [43].

The biochars derived from the secondary residues (SS, $\mathrm{BF}, \mathrm{CM}, \mathrm{PM}$ ) were all low to moderate in $\mathrm{C}$ content but rich in ash and plant nutrients. In a related study, manure-derived biochars were also found to be nutrient-rich and low in $\mathrm{C}$ content which is obvious since manure-as well as biogas fibers and modern sewage sludge from treatment plants with biogas production,- - is the residual part after digestion hence containing less $\mathrm{C}$ and therefore a higher concentration of nutrients than the original biomass [45]. Such biochars were reported to be valuable for agricultural soils nutrient management [46]. It may be argued that with the comparatively low application rates of these P-rich substrates, the $\mathrm{C}$ loss from post-process treatment of low-C biochar is a limited cost that could potentially be made up for in other ways. One such way could be by combining material with a markedly increased P-plant availability with a co-application of high$\mathrm{C}$ substrates like the biochar produced from two primary biomass residues (WC and WS) (Table 2). In this study, the WCB had the highest $\mathrm{C}$ content of the two due to a higher ash content in WSB, possibly due to a high potassium and silicon content in straw tissues [47]. Co-applying C-rich biochar with the P-rich substrates from e.g. post-process steam gasification of poultry manure biochar can be expected to positively influence many soil properties like CEC, soil WHC, soil $\mathrm{pH}$, soil bulk density and soil structure $[23,48$, 49].

Generally, agricultural soils have CEC values between 5 and $15 \mathrm{cmol} / \mathrm{kg}$ [50]. On the other hand, the humic substances $(>100 \mathrm{cmol} / \mathrm{kg})$ and some biochars $(137 \mathrm{cmol} / \mathrm{kg})$ can have a high CEC [51]. Accordingly, the C-rich biochar used as soil conditioner significantly increased soil's CEC (Table 6) with a minimum application rate of $0.5 \mathrm{wt} \%$. In addition to improved CEC, the soil samples with biochars from wheat straw or wood chips (1-5 wt $\%$ ) retained more water (20-27\%) (Table 6) at gravity drained equilibrium which is consistent with previous findings in which a biochar-amended ( $2 \mathrm{wt} \%)$ sandy soil retained $15 \%$ more water than the control soil in a short-term experiment [52]. No apparent difference in the effect on WHC was detected in the present work between the two biochar-samples from wood chips and wheat straw. It has been reported that biochar addition improves the water holding capacity especially of course-textured soils and that the effect increases with time in soil-biochar systems $[27,53]$. Some studies have shown increased water retention of soils even at low application rates of biochar [54, 55], but our findings are in agreement with the findings of Blanco-Canqui [56] who concluded that only large amounts of biochar (>15 Mg/ha) could be effective for improving water content in soils.

Related to a decreasing effect on soil bulk density, application of biochar and derived ashes may also increase the pore volume in the soil and increase the soil's surface area per volume ratio. The surface area of soil amendments like biochar is related to the porous structure of the material. Thermally converted biochar or ashes are characterized by different surface area depending on thermal treatment temperature and type of the biomass. That is why a BET surface area of $12.4 \mathrm{~m}^{2} / \mathrm{g}$ was found for PMB which was raised to $333.8 \mathrm{~m}^{2} / \mathrm{g}$ in case of $\mathrm{WBC}$ at the same $\left(600{ }^{\circ} \mathrm{C}\right)$ pyrolysis temperature (Table 5). This trend is in line with the findings of Wang and Liu [57] who reported a quite big variation in the surface area and structure of different biochars. However, when considering the application of both C-rich and P-rich biochars together, possible effects on $\mathrm{P}$ sorption should be investigated, since biochar surface area is a key factor in adsorption mechanisms [58].

The effect on soil $\mathrm{pH}$ from application of biochars and ashes in the present work was limited in most cases, but could be substantial with high application rates of WSB. Usually, the $\mathrm{pH}$ of thermally converted char increases with increasing treatment temperature, but it also depends on the material characteristics [51]. The liming effect of supplying large quantities of $\mathrm{C}$-rich biochar should be investigated when co-applying with a P-rich biochar or biochar derived ash, as $\mathrm{pH}$ has been shown in previous studies to have a substantial effect on P plant availability of such substrates [59].

In addition to soil and substrate characteristics, it is relevant to discuss the system implication of the different thermal treatment systems. From the obtained results, the optimal use of a single slow pyrolysis plant would be to operate in campaigns with production of (i) untreated biochar from straw or wood for soil enhancement plus, (ii) post process gasification ash from P-rich substrates except sewage sludge. However, pyrolysis without post-process treatment has the obvious advantage of being a simpler and fully commercial process that may be directly applied. In addition, systems without post process treatment of the P-rich biochar open the possibility to co-pyrolyze the P-rich and C-rich organic resources in the proper mixing ratio. Depending on the substrates, this may provide additional benefits e.g. the 
avoided requirement to dry the P-rich substrate, as it has been previously shown with sewage sludge and straw in lowtemperature gasification [18]. In such co-pyrolysis systems it should be investigated how the thermal treatment affects the substrate chemistry with regard to e.g. P plant availability [60-62]. In all cases, the post process char treatment increased $\mathrm{P}$ fertilizer quality compared to the biochar, and in certain cases - here the poultry manure, it may even increase it beyond the level of the untreated biomass. When applying post-process oxidation, it is likely to be most viable to blend the oxidized P-rich ash with C-rich biochar after the thermal processing, but a hybrid should be examined in future studies to determine potential effects of adding the P-rich post-treatment ashes to the subsequent pyrolysis of $\mathrm{C}$-rich material. Including post-process biochar oxidation may give an additional heat output compared to pyrolysis-only, but will also render the system more complicated and expensive. Pyrolysis with post-process steam gasification of biochar may be somewhat achieved in staged gasification systems where the energy output may be highly valuable [63, 64].

The poultry manure case highlights the findings of the present study and showed that is it possible to severely concentrate $\mathrm{P}$ as well as substantially increase the $\mathrm{P}$ fertilizer quality of this feedstock by combined slow pyrolysis and post process char treatment through oxidation or steam gasification. The main product costs of the PM treatment were limited losses of $\mathrm{S}, \mathrm{N}$ and $\mathrm{C}$. Using the same pyrolysis plant in campaign operation, it is possible to combine the production of this poultry manure based $\mathrm{P}$ fertilizer substrate with conversion of wood chips or wheat straw resulting in a co-production of a C-rich biochar for enhancement of soil properties. In this way, one plant can be applicable for addressing two relevant issues to modern agricultural practice-improve use-re-use strategies for $\mathrm{P}$ and increase soil carbon content and soil fertility properties.

\section{Conclusion}

The results of this study show that flexible operation of slow pyrolysis of several broadly available organic resources may provide a suitable platform for production of $\mathrm{P}$ rich fertilizer substrates with high plant availability as well as C-rich chars with soil enhancing properties. Pyrolysis-based thermal treatments of biomass residues can concentrate $\mathrm{C}, \mathrm{P}$ and other essential plant nutrients in the resulting biochars and ashes and such systems can potentially provide a high $\mathrm{P}$-fertilizer value and increased soil $\mathrm{C}$ content with the associated benefits for soil fertility at the same time. However, variations are substantial and there are many parameters to evaluate when considering which thermal treatment to apply and which organic resources to convert.
A few general trends in the results may guide future development. All thermal treatments increased concentration of non-volatile nutrients e.g. P, Mg and $\mathrm{K}$ but caused a loss of volatile nutrients $\mathrm{S}$ and $\mathrm{N}$. With respect to increasing available $\mathrm{P}$ in soils, the gasification ash was found to be better than the pyrolysis biochar and oxidation ash. The C-rich biochars improved soil agronomic properties such as WHC, SOM and $\mathrm{pH}$, with minimum application rates of 0.5-1.0 $\mathrm{wt} \%$. Assessed by the nutrient concentration, nutrient losses and effects on P plant availability, the most promising candidate found in the present work for thermal production of $\mathrm{P}$ fertilizer was oxidation or gasification ash from pyrolysis of poultry manure. In addition, the gasification ash from cattle manure pyrolysis seemed to be an interesting alternative to the untreated organic substrate especially when also considering the potential benefits of thermal purification, stabilization, nutrient concentration and energy recovery. It is proposed to co-apply - and in some cases, co-producesuch P-rich substrates with C-rich biochar from pyrolysis of WS or WC to further enhance soil fertility and crop growth through improved soil fertility parameters such as WHC and CEC.

This concept could prove to be a step forward on the state of the art of $\mathrm{P}$ management technologies and a valuable solution to the challenge of $\mathrm{P}$ supply, recovery and redistribution, as well as $\mathrm{C}$ sequestration, soil fertility enhancement and a reduction of environmental problems related to the inappropriate management of secondary biomass resources.

Funding The research leading to these results received funding from the European Union's Horizon 2020 research and innovation program under the Marie Sklodowska-Curie Grant Agreement No. 713683 (COFUNDfellowsDTU).

Data Availability No additional datasets were generated or analyzed during the current study.

\section{Compliance with Ethical Standards}

Conflict of interest The authors declare no conflicts of interest or competing interests.

Open Access This article is licensed under a Creative Commons Attribution 4.0 International License, which permits use, sharing, adaptation, distribution and reproduction in any medium or format, as long as you give appropriate credit to the original author(s) and the source, provide a link to the Creative Commons licence, and indicate if changes were made. The images or other third party material in this article are included in the article's Creative Commons licence, unless indicated otherwise in a credit line to the material. If material is not included in the article's Creative Commons licence and your intended use is not permitted by statutory regulation or exceeds the permitted use, you will need to obtain permission directly from the copyright holder. To view a copy of this licence, visit http://creativecommons.org/licenses/by/4.0/. 


\section{References}

1. Cordell, D., White, S.: Life's bottleneck: sustaining the World's phosphorus for a food secure future. Annu. Rev. Environ. Resour. 39, 161-188 (2014). https://doi.org/10.1146/annurev-envir on-010213-113300

2. Chowdhury, R.B., Moore, G.A., Weatherley, A.J., Arora, M.: Key sustainability challenges for the global phosphorus resource, their implications for global food security, and options for mitigation. J. Clean Prod. 140, 945-963 (2017). https://doi.org/10.1016/j.jclep ro.2016.07.012

3. Klinglmair, M., Vadenbo, C., Astrup, T.F., Scheutz, C.: An MFAbased optimization model for increased resource efficiency: phosphorus flows in Denmark. Resour. Conserv. Recycl. 122, 1-10 (2017). https://doi.org/10.1016/j.resconrec.2017.01.012

4. Tonini, D., Martinez-sanchez, V., Astrup, T.F.: Material resources, energy, and nutrient recovery from waste: are waste refineries the solution for the future? . Environ. Sci. Technol. 47, 8962-8969 (2013). https://doi.org/10.1021/es400998y

5. Hanserud, O.S., Lyng, K.A., De Vries, J.W., Øgaard, A.F., Bratteb $\varnothing$, H.: Redistributing phosphorus in animal manure from a livestock-intensive region to an Arable region: exploration of environmental consequences. Sustain. (2017). https://doi.org/10.3390/ su9040595

6. Thomsen, T.P., Ravenni, G., Holm, J.K., Ahrenfeldt, J., Hauggaard-Nielsen, H., Henriksen, U.B.: Screening of various lowgrade biomass materials for low temperature gasification: method development and application. Biomass Bioenergy. 79, 128-144 (2014). https://doi.org/10.1016/j.biombioe.2014.12.019

7. Kirchmann, H., Börjesson, G., Kätterer, T., Cohen, Y.: From agricultural use of sewage sludge to nutrient extraction: a soil science outlook. Ambio. 46, 143-154 (2017). https://doi.org/10.1007/ s13280-016-0816-3

8. Mackay, J.E., Cavagnaro, T.R., Jakobsen, I., Macdonald, L.M., Grønlund, M., Thomsen, T.P., Müller-Stöver, D.S.: Evaluation of phosphorus in thermally converted sewage sludge: $\mathrm{P}$ pools and availability to wheat. Plant Soil. 418, 307-317 (2017). https://doi. org/10.1007/s11104-017-3298-6

9. Thomsen, T.P., Sárossy, Z., Ahrenfeldt, J., Henriksen, U.B., Frandsen, F.J., Müller-Stöver, D.S.: Changes imposed by pyrolysis, thermal gasification and incineration on composition and phosphorus fertilizer quality of municipal sewage sludge. J. Environ. Manag. 198, 308-318 (2017). https://doi.org/10.1016/j.jenvm an.2017.04.072

10. Seggiani, M., Puccini, M., Raggio, G., Vitolo, S.: Effect of sewage sludge content on gas quality and solid residues produced by cogasification in an updraft gasifier. Waste Manag. 32, 1826-1834 (2012). https://doi.org/10.1016/j.wasman.2012.04.018

11. Glaser, B., Lehr, V.I.: Biochar effects on phosphorus availability in agricultural soils: a meta-analysis. Sci. Rep. 9, 1-9 (2019). https ://doi.org/10.1038/s41598-019-45693-z

12. Thomsen, T.P., Hauggaard-Nielsen, H., Gøbel, B., Stoholm, P., Ahrenfeldt, J., Henriksen, U.B., Müller-Stöver, D.S.: Low temperature circulating fluidized bed gasification and co-gasification of municipal sewage sludge. Part 2: evaluation of ash materials as phosphorus fertilizer. Waste Manag. 66, 145-154 (2017). https:// doi.org/10.1016/J.WASMAN.2017.04.043

13. Parés Viader, R., Jensen, P.E., Ottosen, L.M., Ahrenfeldt, J., Hauggaard-Nielsen, H.: Electrodialytic extraction of phosphorus from ash of low-temperature gasification of sewage sludge. Electrochim. Acta (2015). https://doi.org/10.1016/j.electacta.2015.05.025

14. Gorazda, K., Tarko, B., Wzorek, Z., Kominko, H., Nowak, A.K., Kulczycka, J., Henclik, A., Smol, M.: Fertilisers production from ashes after sewage sludge combustion-a strategy towards sustainable development. Environ. Res. 154, 171-180 (2017). https://doi.org/10.1016/j.envres.2017.01.002

15. Weigand, H., Bertau, M., Hübner, W., Bohndick, F., Bruckert, A.: RecoPhos: full-scale fertilizer production from sewage sludge ash. Waste Manag. 33, 540-544 (2013). https://doi.org/10.1016/j. wasman.2012.07.009

16. Nanzer, S., Oberson, A., Berger, L., Berset, E., Hermann, L., Frossard, E.: The plant availability of phosphorus from thermochemically treated sewage sludge ashes as studied by 33P labeling techniques. Plant Soil. 377, 439-456 (2014). https://doi. org/10.1007/s11104-013-1968-6

17. Desmidt, E., Ghyselbrecht, K., Zhang, Y., Pinoy, L., Van der Bruggen, B., Verstraete, W., Rabaey, K., Meesschaert, B.: Global phosphorus scarcity and full-scale P-recovery techniques: a review. Crit. Rev. Environ. Sci. Technol. 45, 336-384 (2015). https://doi.org/10.1080/10643389.2013.866531

18. Thomsen, T.P., Sárossy, Z., Gøbel, B., Stoholm, P., Ahrenfeldt, J., Frandsen, F.J., Henriksen, U.B.: Low temperature circulating fluidized bed gasification and co-gasification of municipal sewage sludge. Part 1: process performance and gas product characterization. Waste Manag. 66, 123-133 (2017). https://doi.org/10.1016/j. wasman.2017.04.028

19. Lua, A.C.: A detailed study of pyrolysis conditions on the production of steam-activated carbon derived from oil-palm shell and its application in phenol adsorption. Biomass Convers. Biorefinery. 10, 523-533 (2020). https://doi.org/10.1007/s13399-019-00447-9

20. Ravenni, G., Cafaggi, G., Sárossy, Z., Rohde Nielsen, K.T., Ahrenfeldt, J., Henriksen, U.B.: Waste chars from wood gasification and wastewater sludge pyrolysis compared to commercial activated carbon for the removal of cationic and anionic dyes from aqueous solution. Bioresour. Technol. Reports. 10, 100421 (2020). https://doi.org/10.1016/j.biteb.2020.100421

21. Imparato, V., Hansen, V., Santos, S.S., Nielsen, T.K., Giagnoni, L., Hauggaard-Nielsen, H., Johansen, A., Renella, G., Winding, A.: Gasification biochar has limited effects on functional and structural diversity of soil microbial communities in a temperate agroecosystem. Soil Biol. Biochem. 99, 128-136 (2016). https:// doi.org/10.1016/j.soilbio.2016.05.004

22. Hansen, V., Müller-Stöver, D., Imparato, V., Krogh, P.H., Jensen, L.S., Dolmer, A., Hauggaard-Nielsen, H.: The effects of straw or straw-derived gasification biochar applications on soil quality and crop productivity: a farm case study. J. Environ. Manag. 186, 88-95 (2017). https://doi.org/10.1016/j.jenvman.2016.10.041

23. Bruun, E.W., Petersen, C.T., Hansen, E., Holm, J.K., HauggaardNielsen, H.: Biochar amendment to coarse sandy subsoil improves root growth and increases water retention. Soil Use Manag. 30, 109-118 (2014). https://doi.org/10.1111/sum.12102

24. Tan, Z., Lin, C.S.K., Ji, X., Rainey, T.J.: Returning biochar to fields: a review. Appl. Soil Ecol. 116, 1-11 (2017). https://doi. org/10.1016/j.apsoil.2017.03.017

25. Omondi, M.O., Xia, X., Nahayo, A., Liu, X., Korai, P.K., Pan, G.: Quantification of biochar effects on soil hydrological properties using meta-analysis of literature data. Geoderma. 274, 28-34 (2016). https://doi.org/10.1016/j.geoderma.2016.03.029

26. Xiang, Y., Deng, Q., Duan, H., Guo, Y.: Effects of biochar application on root traits: a meta-analysis. GCB Bioenergy. 9, 1563-1572 (2017). https://doi.org/10.1111/gcbb.12449

27. Laghari, M., Mirjat, M.S.M.S., Hu, Z., Fazal, S., Xiao, B.B., Hu, M., Chen, Z., Guo, D.: Effects of biochar application rate on sandy desert soil properties and sorghum growth. Catena. 135, 313-320 (2015). https://doi.org/10.1016/j.catena.2015.08.013

28. Pratt, C., Redding, M., Hill, J., Mudge, S.R., Westermann, M., Paungfoo-Lonhienne, C., Schmidt, S.: Assessing refrigerating and freezing effects on the biological/chemical composition of two 
livestock manures. Agric. Ecosyst. Environ. 197, 288-292 (2014). https://doi.org/10.1016/j.agee.2014.08.012

29. Brewer, C.E., Chuang, V.J., Masiello, C.A., Gonnermann, H., Gao, X., Dugan, B., Driver, L.E., Panzacchi, P., Zygourakis, K., Davies, C.A.: New approaches to measuring biochar density and porosity. Biomass Bioenergy. 66, 176-185 (2014). https://doi. org/10.1016/j.biombioe.2014.03.059

30. Wu, W., Yang, M., Feng, Q., McGrouther, K., Wang, H., Lu, H., Chen, Y.: Chemical characterization of rice straw-derived biochar for soil amendment. Biomass Bioenergy. 47, 268-276 (2012). https://doi.org/10.1016/j.biombioe.2012.09.034

31. Gascó, G., Paz-Ferreiro, J., Álvarez, M.L., Saa, A., Méndez, A.: Biochars and hydrochars prepared by pyrolysis and hydrothermal carbonisation of pig manure. Waste Manag. 79, 395-403 (2018). https://doi.org/10.1016/J.WASMAN.2018.08.015

32. Wang, Q., Han, K., Qi, J., Zhang, J., Li, H., Lu, C.: Investigation of potassium transformation characteristics and the influence of additives during biochar briquette combustion. Fuel. 222, 407415 (2018). https://doi.org/10.1016/J.FUEL.2018.02.156

33. Frišták, V., Pipíška, M., Soja, G.: Pyrolysis treatment of sewage sludge: a promising way to produce phosphorus fertilizer. J. Clean. Prod. 172, 1772-1778 (2018). https://doi.org/10.1016/j. jclepro.2017.12.015

34. Acelas, N.Y., López, D.P., Wim Brilman, D.W.F., Kersten, S.R.A., Kootstra, A.M.J.: Supercritical water gasification of sewage sludge: gas production and phosphorus recovery. Bioresour. Technol. 174, 167-175 (2014). https://doi.org/10.1016/j.biort ech.2014.10.003

35. Colantoni, A., Evic, N., Lord, R., Retschitzegger, S., Proto, A.R., Gallucci, F., Monarca, D.: Characterization of biochars produced from pyrolysis of pelletized agricultural residues. Renew. Sustain. Energy Rev. 64, 187-194 (2016). https://doi.org/10.1016/J. RSER.2016.06.003

36. de Figueiredo, C.C., Chagas, J.K.M., da Silva, J., Paz-Ferreiro, J.: Short-term effects of a sewage sludge biochar amendment on total and available heavy metal content of a tropical soil. Geoderma. 344, 31-39 (2019). https://doi.org/10.1016/j.geode rma.2019.01.052

37. Wang, X., Chi, Q., Liu, X., Wang, Y.: Influence of pyrolysis temperature on characteristics and environmental risk of heavy metals in pyrolyzed biochar made from hydrothermally treated sewage sludge. Chemosphere. 216, 698-706 (2019). https://doi. org/10.1016/j.chemosphere.2018.10.189

38. Hansen, M., Björklund, E., Popovic, O., Jensen, L.S., Jacobsen, C.S., Sedlak, D.L., Halling-Sørensen, B.: Animal manure separation technologies diminish the environmental burden of steroid hormones. Environ. Sci. Technol. Lett. 2, 133-137 (2015). https ://doi.org/10.1021/acs.estlett.5b00059

39. Kumaragamage, D., Akinremi, O.O., Grieger, L.: Phosphorus fractions in solid and liquid separates of swine slurry separated using different technologies. J. Environ. Qual. 42, 1863-1871 (2013). https://doi.org/10.2134/jeq2013.03.0074

40. Kahiluoto, H., Kuisma, M., Ketoja, E., Salo, T., Heikkinen, J.: Phosphorus in manure and sewage sludge more recyclable than in soluble inorganic fertilizer. Environ. Sci. Technol. 49, 2115-2122 (2015). https://doi.org/10.1021/es503387y

41. Sánchez-Esteva, S., Gómez-Muñoz, B., Jensen, L.S., de Neergaard, A., Magid, J.: The effect of Penicillium bilaii on wheat growth and phosphorus uptake as affected by soil $\mathrm{pH}$, soil $\mathrm{P}$ and application of sewage sludge. Chem. Biol. Technol. Agric. 3, 1-11 (2016). https://doi.org/10.1186/s40538-016-0075-3

42. Qian, T., Jiang, H.: Migration of phosphorus in sewage sludge during different thermal treatment processes. Sustain. Chem. Eng. 2, 1411-1419 (2014)

43. Robinson, J.S., Baumann, K., Hu, Y., Hagemann, P., Kebelmann, L., Leinweber, P.: Phosphorus transformations in plant-based and bio-waste materials induced by pyrolysis. Ambio. 47, 73-82 (2018). https://doi.org/10.1007/s13280-017-0990-y

44. Qian, T., Wang, L., Le, C., Zhou, Y.: Low-temperature-steam activation of phosphorus in biochar derived from enhanced biological phosphorus removal (EBPR) sludge. Water Res. 161, 202-210 (2019). https://doi.org/10.1016/j.watres.2019.06.008

45. Mao, J., Zhang, K., Chen, B.: Linking hydrophobicity of biochar to the water repellency and water holding capacity of biocharamended soil. Environ. Pollut. 253, 779-789 (2019). https://doi. org/10.1016/j.envpol.2019.07.051

46. Zornoza, R., Moreno-Barriga, F., Acosta, J.A., Muñoz, M.A., Faz, A.: Stability, nutrient availability and hydrophobicity of biochars derived from manure, crop residues, and municipal solid waste for their use as soil amendments. Chemosphere. 144, 122-130 (2016). https://doi.org/10.1016/j.chemosphere.2015.08.046

47. $\mathrm{Xu}, \mathrm{Y}$., Chen, B.: Investigation of thermodynamic parameters in the pyrolysis conversion of biomass and manure to biochars using thermogravimetric analysis. Bioresour. Technol. 146, 485-493 (2013). https://doi.org/10.1016/j.biortech.2013.07.086

48. Liang, B., Lehmann, J., Solomon, D., Kinyangi, J., Grossman, J., O’Neill, B., Skjemstad, J.O., Thies, J., Luizão, F.J., Petersen, J., Neves, E.G.: Black carbon increases cation exchange capacity in soils. Soil Sci. Soc. Am. J. 70, 1719 (2006). https://doi. org/10.2136/sssaj2005.0383

49. Wang, B., Lehmann, J., Hanley, K., Hestrin, R., Enders, A.: Adsorption and desorption of ammonium by maple wood biochar as a function of oxidation and $\mathrm{pH}$. Chemosphere. 138, 120 126 (2015). https://doi.org/10.1016/j.chemosphere.2015.05.062

50. Günal, E., Erdem, H., Çelik, İ: Effects of three different biochars amendment on water retention of silty loam and loamy soils. Agric. Water Manag. 208, 232-244 (2018). https://doi. org/10.1016/j.agwat.2018.06.004

51. Cely, P., Gascó, G., Paz-Ferreiro, J., Méndez, A.: Agronomic properties of biochars from different manure wastes. J. Anal. Appl. Pyrolysis. 111, 173-182 (2015). https://doi.org/10.1016/J. JAAP.2014.11.014

52. Laird, D.A., Fleming, P., Davis, D.D., Horton, R., Wang, B., Karlen, D.L.: Impact of biochar amendments on the quality of a typical Midwestern agricultural soil. Geoderma. 158, 443-449 (2010). https://doi.org/10.1016/j.geoderma.2010.05.013

53. Razzaghi, F., Obour, P.B., Arthur, E.: Does biochar improve soil water retention? A systematic review and meta-analysis. Geoderma. 361, 114055 (2020). https://doi.org/10.1016/j.geode rma.2019.114055

54. Laghari, M., Naidu, R., Xiao, B.B., Hu, Z., Mirjat, M.S., Hu, M., Kandhro, M.N., Chen, Z., Guo, D., Jogi, Q., Abudi, Z.N., Fazal, S.: Recent developments in biochar as an effective tool for agricultural soil management: a review. J. Sci. Food Agric. 96, 4840-4849 (2016). https://doi.org/10.1002/jsfa.7753

55. Laghari, M., Hu, Z., Mirjat, M.S.M.S., Xiao, B.B., Tagar, A.A., $\mathrm{Hu}, \mathrm{M} .:$ Fast pyrolysis biochar from sawdust improves the quality of desert soils and enhances plant growth. J. Sci. Food Agric. 96, 199-206 (2016). https://doi.org/10.1002/jsfa.7082

56. Blanco-Canqui, H.: Biochar and Soil Physical Properties. Soil Sci. Soc. Am. J. 81, 687 (2017). https://doi.org/10.2136/sssaj 2017.01.0017

57. Wang, Y., Liu, R.: Comparison of characteristics of twenty-one types of biochar and their ability to remove multi-heavy metals and methylene blue in solution. Fuel Process. Technol. 160, 55-63 (2017). https://doi.org/10.1016/j.fuproc.2017.02.019

58. Antunes, E., Schumann, J., Brodie, G., Jacob, M.V., Schneider, P.A.: Biochar produced from biosolids using a single-mode microwave: Characterisation and its potential for phosphorus removal. J. Environ. Manage. 196, 119-126 (2017). https://doi. org/10.1016/j.jenvman.2017.02.080 
59. Li, X., Rubæk, G.H., Müller-Stöver, D.S., Thomsen, T.P., Ahrenfeldt, J., Sørensen, P.: Plant availability of phosphorus in five gasification biochars. Geoderma. (2016). https://doi. org/10.3389/fsufs.2017.00002

60. Li, L., Ren, Q., Li, S., Lu, Q.: Effect of phosphorus on the behavior of potassium during the co- combustion of wheat straw with municipal sewage sludge. Energy Fuels. 27, 5923-5930 (2013)

61. Lopes, M.H., Abelha, P., Lapa, N., Oliveira, J.S., Cabrita, I., Gulyurtlu, I.: The behaviour of ashes and heavy metals during the co-combustion of sewage sludges in a fluidised bed. Waste Manag. 23, 859-870 (2003). https://doi.org/10.1016/S0956 $-053 X(03) 00025-4$

62. Jiang, L.B., Yuan, X.Z., Li, H., Chen, X.H., Xiao, Z.H., Liang, J., Leng, L.J., Guo, Z., Zeng, G.M.: Co-pelletization of sewage sludge and biomass: thermogravimetric analysis and ash deposits. Fuel Process. Technol. 145, 109-115 (2016). https://doi. org/10.1016/j.fuproc.2016.01.027
63. Henriksen, U., Ahrenfeldt, J., Jensen, T.K., Gøbel, B., Bentzen, J.D., Hindsgaul, C., Sørensen, L.H.: The design, construction and operation of a $75 \mathrm{~kW}$ two-stage gasifier. Energy. 31, 1542-1553 (2006). https://doi.org/10.1016/j.energy.2005.05.031

64. Ahrenfeldt, J., Thomsen, T.P.T.P., Henriksen, U., Clausen, L.R.L.R.: Biomass gasification cogeneration-a review of state of the art technology and near future perspectives. Appl. Therm. Eng. 50, 1407-1417 (2013). https://doi.org/10.1016/j.appltherma leng.2011.12.040

Publisher's note Springer Nature remains neutral with regard to jurisdictional claims in published maps and institutional affiliations. 